\title{
Cardiac Angiosarcoma:A case report and review of the literature
}

\author{
Limin Luo ${ }^{1}$, Weipeng Zhao ${ }^{2}$, and Kun Liu $^{1}$ \\ ${ }^{1}$ Affiliation not available \\ ${ }^{2}$ Shanghai Institute of Cardiovascular Disease, Zhongshan Hospital, Fudan University
}

June 21, 2021

\begin{abstract}
Primary cardiac tumors are extremely rare.Most primary tumors are benign, and malignant tumors comprise about $15 \% 1$. Angiosarcoma is the most common type of primary cardiac malignant tumors. Compared with the left atrium or ventricle,the tumor prefer to occur in the right atrium or ventricle,especially the right atrium.In this case report,we present the case of a 32-year-old female with cardiac angiosarcoma primary to the right atrial appendage(RAA).
\end{abstract}

\section{Hosted file}

Case report Document.pdf available at https://authorea.com/users/420939/articles/527149cardiac-angiosarcoma-a-case-report-and-review-of-the-literature

\section{Hosted file}

Case report images.pdf available at https://authorea.com/users/420939/articles/527149cardiac-angiosarcoma-a-case-report-and-review-of-the-literature 